\section{Adapting Participatory Design Tools in Design Through Research (DTR) Models to Develop Sustainable Projects in Sensitive Territories. Case Analysis}

\section{Gerda Antanaitytè}

Klaipeda University, Faculty of Humanities and Education Sciences, Department of Philosophy and Culturology, S. Neries st. 5, 92227, Klaipeda

\section{Inga Urbonaitè-Vadokliené*}

LCC international university, LCC innovation lab, Kretingos g. 36, LT- 92307 Klaipeda, Lithuania

*Corresponding author: inga.urbonaite@yahoo.com

\section{$\Gamma$} Crossef http://dx.doi.org/10.5755/j01.sace.20.3.14055

Urban development, or architectural design in fragile (sensitive) territories is always complicated, especially when one considers national, regional, reserve parks, or other territories that have a lot of sociocultural meaning to society, and local communities. Existing bureaucratic procedures complicate community involvement into planning process, and creativity manifestation in decision making is vague.

The article analyses three design through research project cases developed by authors, which share common goal - to improve the quality of the environment using innovative and contemporary solutions, deal with landscape sustainability and local identity issues by involving community into design process.

Presented samples reveal three different design through research and participatory design models. In each case site planning projects are initiated by different groups, therefore motives for the project implementation differ. That determines the sample of public inclusion, scope of fulfilled research, design solutions and capabilities for sustainability of the project. Comparative analysis of these cases summarize strengths and weaknesses of each model and form recommendations for similar territorial development in the future.

Keywords: sustainable design process, participatory design, sensitive territories, community engagement, urban design, cultural identity.

Interaction of anthropogenic and natural processes forms distinctive and unique character of a place, which is identified as genius loci and valued as one of the main aspects of sustainable architecture. On the other hand, urban designers and architects quite often face a challenge to comprehend the identity of a place, by uncovering apparent layers of cultural landscape and articulating their value in actual contemporary architectural forms. Every urban development, or architectural design in sensitive territories meets a challenge of prioritization, and the need to find balance between natural landscape, local resources, and sociocultural factors is essential. Following strict rules and planning regulations is not always the answer as it sometimes becomes a formal procedure for bureaucrats to ban innovative solutions. Such solutions would not only

\section{Introduction

ktu

Journal of Sustainable Architecture and Civil Engineering Vol. 3 / No. 20 / 2017 pp. 5-13

DOI 10.5755/j01.sace.20.3.14055 (c) Kaunas University of Technology 
improve ecological quality of the territory, but would also be relevant to local communities and cover their needs. Instead, quite often the quality of aesthetic design solutions suffers, because a more common approach of imitation is chosen over interpretation of established architectural forms. One of the main reasons for such complicated development in sensitive territories is a lack of proper models of the design process.

Theory and practice of contemporary urban design pays a lot of attention to community involvement into the design process and the models of design process itself. The concept of sustainable development aims to find consensus among different stakeholders and balance different needs (Sobandi and Sudarmadji, 2015). Public participation is the process by which the public concerns, need and values are incorporated into governmental and corporate decision making (Ismaila and Saidb, 2015). Collaboration theory defines the importance of facilitating participation of multidisciplinary teams and stakeholders (Morales, 2013). Relation, networking, coordinating, and cooperating is as essential as non-hierarchical relationships among different groups of interests. It is when planning process is understood as developmental continuum and previous strategies are incorporated into the new ones (Himmelman, 2002).

In Lithuania, after implementation of the new law of spatial planning in 2014 (Lietuvos, 2013), new rules regarding the coordination of public interest were set. By giving the right of regulation and organization of city planning to municipalities, the public involvement became very relevant. Although this law eliminated a lot of problems that existed in the field, some researches argue that legal formulation of the new law has limited public interest representation and serves only to certain groups of interests (Lastauskienè and Bakštienè, 2015). It seems that public interest is protected only in certain fixed cases which are set by rules without actual possibility to critically and creatively approach the territory planning process. For this reason, it is essential to educate society and form the practice of public involvement through sustainable territory planning models. Especially public interest should be protected when dealing with sensitive territories. It is evident that even unsuccessful planning processes or unrealized projects raise public awareness and social self-consciousness, i.e. the society's ability to concentrate, discuss and influence the governmental institutions, pass the determined decisions and precondition the unexpected course of architectural processes, is established (Gudelytè-Račienè, 2017).

Participatory planning model is already widely spread and implemented in various forms around the world (Cauchi-Santoro, 2016; Proli, 2011; Shuib et al., 2015; Rasoolimanesh et al., 2017; Stewart et al., 2004 and many more), however it is still quite a fresh and not recognized practice in Lithuania. Facilitation of such projects is quite a new phenomenon; especially in Lithuanian context, where quite often it becomes a challenge due to lack of human resources and competences.

Nevertheless, participatory development is the most important approach towards enabling communities to help themselves and sustain efforts in development work (Cirtautas, 2011). Communities are no longer seen as recipients of development programs; rather, they have become critical stakeholders that have an important role to play in the management of programs and projects in their areas. In this context it is more relevant to talk about territorial and local communities which are in one or another way physically connected to certain territory and might have various, quite often contrary needs and interests (Urbonaite, 2011).

Traditionally, architects and designers carry all responsibility for the design process, as they deliver final design solutions to approving institutions. The latter are officially responsible for balancing the needs of different stakeholders. However, in reality, lack of their involvement in the development process, complex understanding of territory, and interdisciplinary collaboration is evident. 
Another important problem is the implementation of design solutions and continuity of the project. Sustainable and qualitative result is inherent in communicating, informing and educating related communities and stakeholders. Only those parties, who are capable of recognizing the identity, meanings and coded values of a certain sensitive territory, are capable of later taking care of it and feeling connected. $Q$ methodology is quite often used to assess the diversity of opinions among the community, produce new themes for a group of people and subsequently be used in improving the quality of developed territory. Such approach allows to connect qualitative and quantitative data concerning perceptions, beliefs, attitudes, opinions or viewpoints of different stakeholders (Shuib et al., 2015).

There are three main operating sides that shape the environment: professionals (architects), institutions (municipality, national parks, nature protection, cultural heritage department etc.) and community.

Each of the interested parts has its own approach to environmental development, therefore dedicating decision making to one of the parts, disregarding interests and knowledge of the rest of interested groups affect quality of the whole project.

The purpose of this study is to identify the effectiveness of particular practical approaches in dealing with participatory design models in sensitive territories of Lithuania.

\section{Methodology and Research design}

Case study approach has an emphasis on detailed and relativity based analysis on particular set of conditions, data sets or subjects. The method is open to the variety of disciplines, but relative to our case, qualitative research method is used by contemporary sociologists to examine real-life situations to provide basis for the future development and application of ideas and methods. As defined by researcher Robert K. Yin, the case study method is an empirical inquiry that investigates a contemporary phenomenon within its real-life context; when the boundaries between phenomenon and context are not clearly evident; and in which multiple sources of evidence are used (Yin, 1984).

Case study method was selected to compare three participatory design projects developed in last three years in sensitive Lithuanian territories: creative workshop and architectural competition aimed to create small scale architectural objects reflecting spirit of the place genius loci in Curonian Spit, UNESCO World Heritage Site; Feasibility study development for Karklè village situated at the Seaside Regional Park; Landscape formation and environmental condition improvement project for Sablauskiai Pond access situated at Akmene district. Comparative analysis of these cases summarizes strengths and weaknesses of each model and forms recommendations for similar territorial development in the future. Research authors were engaged in mentioned projects as a part of initiating and content creating groups and had opportunity to comprehensively observe and actively engage with the process.

Structure of the research design consists of three following parts:

1. Cases. Three participatory design projects developed in last three years in sensitive Lithuanian territories;

2. Case study variables. Two main categories of variables that are compared;

3. Data analysis. Investigation of interaction between different case study variables and generated results.

\section{Cases}

\section{Project 1. Architectural Stops in Curonian Spit}

The project was initiated by Non-Governmental Organisation - Architect A. Zaviša Charity and 
Support Foundation (in the following paragraphs - AZF) as an experimental method to design small scale contemporary architecture projects in Curonian Spit. Curonian Spit is a highly protected area in Lithuanian seaside. The territory is UNESCO World Heritage site and belongs to Curonian Spit National Park. Architectural expression of traditional fishermen houses dominates in the site. Prevailed imitative approach as the only right or safe way to design in the area and lack of contemporary statement was the main problematic issue raised by the initiator. The main purpose of the project was to involve parties into design process from the first architectural design stage thus provoking discussion and finding common ground for the contemporary approach. Selected form of the project was creative workshop and architectural competition where five groups of architects were designing concepts for the bus stops. The project lasted for five months.

\section{Project 2. Karklè Atlas}

The project was initiated by four operating parties: Community of Karkle village, Non-Governmental Organisation (afore mentioned Architect A. Zaviša Charity and Support Foundation), Klaipeda district Municipality and Seaside Regional Park to define guidelines for Karkle village public places development. The village belongs to Seaside Regional Park territory and has Ethnocultural Reserve status. War, political system, urban changes drastically transformed former seaside fisherman village in the past 70 years. Territory's outlasted landscape, demographic, urban structure changes has raised problematic issue to determine contemporary identity of the village by respecting historical cultural and natural layers of the site. The main purpose of the project was to analyse different aspects of the situation and prepare feasibility study for future village development. The project lasted for nine months.

Project 3. Landscape formation and environmental condition improvement project for Sablauskiai Pond access situated at Akmenè district

The project was initiated and coordinated by Akmene region municipality. The initial goal was to develop access to Sablauskiai Pond and improve recreational, ecological and landscape conditions of the beach territory, used by local community. The site is a part of regional natural frame although no strict protection regulations or requirements are determined. Nevertheless, the territory is very interesting and sensitive as the pond is artificial and initially was made by digging Dabikine river. It was used as water source for the local cement plants in 1970s. The landscape has already suffered from anthropogenic activity and ecological biodiversity is still very fragile and emerging.

The driving force of territory development was a possibility to get European funding for landscape formation and environment conditions improvement. The choice of this financial instrument determined the whole design process model and forms of public involvement as it was clearly set in funding application requirements from the very first stage. The crucial problematic was to balance recreational needs of local community with high ecological requirements of the Program. One of the main design process goals was to educate participating parties and provide deeper knowledge about biodiversity and uniqueness of the territory. The project lasted for 9 months.

\section{Case study variables}

There are two main categories of variables that are compared in the following research part:

A. Participants. There are four operating participant parties involved in the project development:

Initiators. Question problematics and determine purpose of the project;

- Coordinators. Trigger project establishment, manage the project and its process;

_ Content creators. Participants generating content of the project; 
Reflective participants. Participants that are directly and indirectly involved in certain stages of the project through giving feedback.

B. Process. Determinates communication, planning and designing models between participants in terms of frequency, duration, involvement roles and responsibilities. Aspects of process evaluation:

_ Form of participatory planning model. Indicates interaction schemes between participants;

- Direct involvement. Indicates frequency and range tools used by coordinator to communicate with project participants;

- Indirect involvement. Indicates frequency and range of communication tools used by coordinator to reach wider audience that is not directly involved in the project;

_ Continuity. Indicates range of tools and initiating parties for future project continuation.

\section{Data analysis}

Data analysis is based on the investigation of interaction between different case study variables and generated results. Project success is determined by evaluating following priorities:

- Project reach. Evaluation of direct and indirect engagement into the project process;

_ Complexity of project management;

_ Complexity of tools. Evaluation of project development model and interaction between participants;

_ Impact on fragile territory. Evaluating the balance of interests, project continuity and the development of the participants' engagement through the following project stages.

Comparative data of the cases and case study variables is presented in the Table 1.

\section{Analysis of the data}

Project 1 was initiated by Non-Governmental Organization. Project development management and tools were quite new at that time, also high level of indirect involvement due to authoritative participants. Architects and scientists involved in the project are well known in their professional fields. The process was widely presented to professionals and national media. We can assume that these features encouraged further project development - implementation of winning project initiated by municipality and book publishing initiated by Non-Governmental Organization. Development model of Project 1 is successful participatory design example and has positive impact on fragile territory in terms of project results acceptance, but lack of project acceptance from local community.

Project 2 was initiated by two equal parties - municipality and community in close cooperation with NGO. During the process content creators were presenting every part of the project to initiators and all reflective participant groups and receiving feedback thus developing the project. Due to the process management, involvement and tight cooperation between all participants in all stages of the project, final results were accepted by all involved parties, furthermore, continuity of the project was initiated by municipality, community and NGO. We can assume that development model of Project 2 is the most successful participatory design example and has significant impact on fragile territory.

Project 3 was initiated and continued by municipality. Due to strict agenda and non-flexible process management from the municipality, the project has poor dissemination and community involvement. The project is continued by initiative of the municipality. 


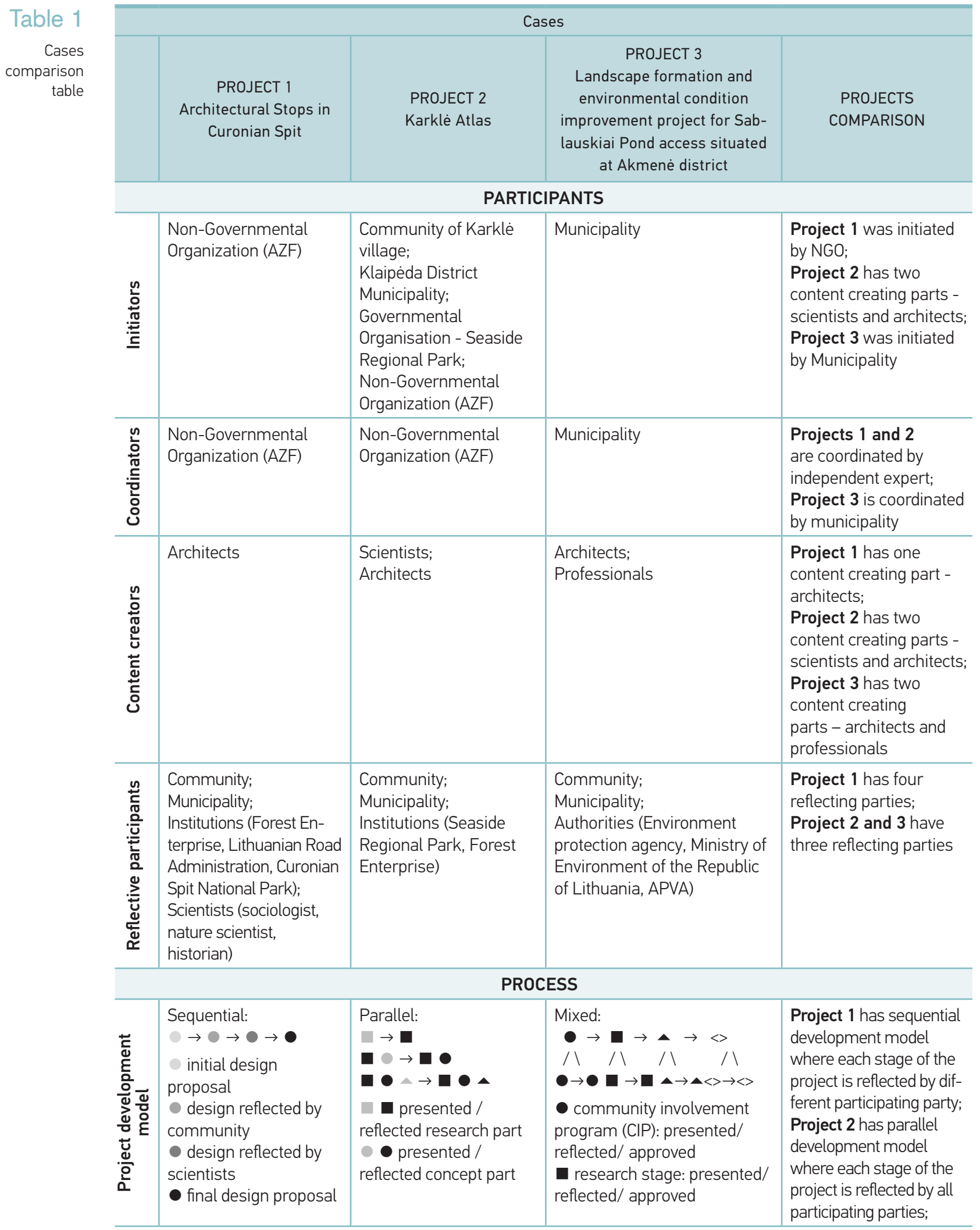




\begin{tabular}{|c|c|c|c|c|}
\hline \multicolumn{5}{|c|}{ Cases } \\
\hline & $\begin{array}{c}\text { PROJECT } 1 \\
\text { Architectural Stops in } \\
\text { Curonian Spit }\end{array}$ & $\begin{array}{l}\text { PROJECT } 2 \\
\text { Karklè Atlas }\end{array}$ & $\begin{array}{c}\text { PROJECT } 3 \\
\text { Landscape formation and } \\
\text { environmental condition } \\
\text { improvement project for Sab- } \\
\text { lauskiai Pond access situated } \\
\text { at Akmenè district }\end{array}$ & $\begin{array}{l}\text { PROJECTS } \\
\text { COMPARISON }\end{array}$ \\
\hline 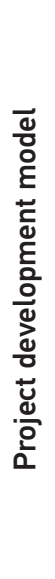 & $\begin{array}{l}\text { All stages of the } \\
\text { project are developed } \\
\text { by content creating } \\
\text { parts (architects). Each } \\
\text { stage is presented to } \\
\text { individual reflective } \\
\text { participant group. The } \\
\text { feedback obtained } \\
\text { from reflective group } \\
\text { support the project } \\
\text { development in the } \\
\text { next stage that will be } \\
\text { presented to following } \\
\text { reflective participants } \\
\text { group }\end{array}$ & $\begin{array}{l}\text { Apresented / } \\
\text { reflected design } \\
\text { proposals part } \\
\text { For every part of the } \\
\text { project that is made } \\
\text { by content creators } \\
\text { (scientists and } \\
\text { architects) is given } \\
\text { feedback from all } \\
\text { reflective participant } \\
\text { groups (municipality, } \\
\text { community and } \\
\text { Governmental } \\
\text { organisation) }\end{array}$ & $\begin{array}{l}\text { - design proposal stage: } \\
\text { presented/ reflected/ } \\
\text { approved } \\
\text { <> technical planning stage: } \\
\text { presented/ reflected/ } \\
\text { approved } \\
\text { First of all Community } \\
\text { involvement program is } \\
\text { prepared which sets the rules } \\
\text { of community participation } \\
\text { in all project stages. Every } \\
\text { stage is presented, reflected } \\
\text { and approved by community, } \\
\text { municipality and authorities }\end{array}$ & $\begin{array}{l}\text { Project } 3 \text { has } \\
\text { mixed development } \\
\text { model where } \\
\text { sequential project } \\
\text { development plan is } \\
\text { set and community } \\
\text { involvement program is } \\
\text { prepared which allows } \\
\text { participating parties to } \\
\text { reflect on the project at } \\
\text { every stage }\end{array}$ \\
\hline 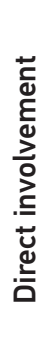 & $\begin{array}{l}\text { Meetings with } \\
\text { participants depending } \\
\text { on needs }\end{array}$ & $\begin{array}{l}\text { Meetings with } \\
\text { participants depending } \\
\text { on needs }\end{array}$ & $\begin{array}{l}\text { Meetings with participants } \\
\text { according the CIP program }\end{array}$ & $\begin{array}{l}\text { Projects } 1 \text { and } 2 \text { have } \\
\text { flexible agenda for } \\
\text { meetings, discussions } \\
\text { and ability to change } \\
\text { programme of the } \\
\text { project depending on } \\
\text { the process; } \\
\text { Project } 3 \text { has strict } \\
\text { program and agenda }\end{array}$ \\
\hline 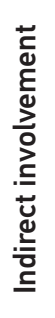 & $\begin{array}{l}\text { Updated information on } \\
\text { the website dedicated to } \\
\text { project development } \\
\text { Projects exhibition } \\
\text { Public event with final } \\
\text { presentations } \\
\text { Publications in media } \\
\text { Published book }\end{array}$ & $\begin{array}{l}\text { Updated information on } \\
\text { the website dedicated to } \\
\text { project development } \\
\text { Public event presenting } \\
\text { results } \\
\text { Publications in media }\end{array}$ & $\begin{array}{l}\text { Updated information } \\
\text { on Akmenè region } \\
\text { municipality website (official } \\
\text { announcements) }\end{array}$ & $\begin{array}{l}\text { Projects } 1 \text { and } 2 \\
\text { have wide range } \\
\text { communicating tools; } \\
\text { Project } 3 \text { information } \\
\text { dissemination is formal } \\
\text { and narrow }\end{array}$ \\
\hline 胥 & $\begin{array}{l}\text { Implementation } \\
\text { of winning project. } \\
\text { Initiated by municipality } \\
\text { Publishing of the book. } \\
\text { Initiated by NGO }\end{array}$ & $\begin{array}{l}\text { Project area extension. } \\
\text { Initiated by municipality } \\
\text { and NGO } \\
\text { Preparation } \\
\text { of a technical } \\
\text { requirements of project } \\
\text { implementation. } \\
\text { Initiated by municipality } \\
\text { and NGO } \\
\text { Development of design } \\
\text { proposals }\end{array}$ & $\begin{array}{l}\text { Preparation of technical } \\
\text { task and technical project. } \\
\text { Initiated by municipality. } \\
\text { Implementation of design } \\
\text { solutions. }\end{array}$ & $\begin{array}{l}\text { Project } 1 \text { is continued } \\
\text { by the initiative of } \\
\text { municipality; } \\
\text { Project } 2 \text { is continued } \\
\text { by initiative of } \\
\text { municipality, institution } \\
\text { and community; } \\
\text { Project } 3 \text { is continued } \\
\text { by municipality }\end{array}$ \\
\hline
\end{tabular}




\section{Discussion} and conclusions

Analysis has shown that participatory design approach is sufficient for the development of sensitive territories. Finding common ground between different interested parts is a complex process which requires debates, understanding and setting right expression tools. Thus sufficient timeframe to experience the process profoundly rather than formally is crucial.

Project 1 was the case of bottom-up initiative where the whole design process was started by an NGO, which, in this case, acted as a community of professional interests. It took time and effort to convince municipality and other authorities to partnership and make further actual steps of project implementation. In such cases, the lack of motivation to bring changes is crucial, especially if it is not fixed in any regulations or formal administrative duties.

It is important to set clear participation rules but also leave space for dynamics and spontaneity during the design process. Project 3 showed that too strict formulations and process management regulations can diminish the motivation to involve and reflect on the ongoing design process.

One of the main aspects of effective participatory design models is the role of competent and independent design process facilitator. The practice of analysed cases showed that municipality can be quite a good project administrator- coordinator, but it should not be forgotten that in reality, municipality is not a neutral stakeholder and must be considered as one of the project participators. Moreover, municipalities quite often lack human resources, competences and lack of freedom to facilitate design processes in a creative and innovative way and for this reason neutral professional facilitators should be chosen. Architects are the ones that are usually expected to manage and facilitate the process. However, architects' role is to synthesize complex information and provide design solutions and for this reason they are considered as experts-participants, who cannot stay neutral when their design solutions are questioned or discussed.

All three projects have reached the technical design project phase and further research could be held to monitor and track the implementation of proposed solutions. As Lithuanian practice shows, design proposals are very often misinterpreted and changed at technical design project stage, especially, when municipalities become responsible for it. For this reason, it is very important that an independent facilitator stays within the project till the very end and makes sure that public interests are protected and sustainable proposals are valid. Especially when it requires complex and long term urban design process coordination.

\section{References}

Cauchi-Santoro, R. Mapping community identity: Safeguarding the memories of a city's downtown core. City, Culture and Society, 2016; 7: 43-54. https://doi.org/10.1016/j.ccs.2015.12.003

Cirtautas, M. Visuomenès dalyvavimo urbanistinio planavimo ir projektavimo procesuose realijos ir perspektyvos/ Reality and perspectives of public participation in urban planning and design processes. K. Šešelgio skaitymai-2011/ K. Šešelgis readings-2011. 2011; 3(3): 59-66.

Cojanua, D. Homo Localis. Interpreting Cultural Identity as Spirit of Place. Procedia - Social and Behavioral Sciences, 2014; 149: 212-216. https://doi. org/10.1016/j.sbspro.2014.08.219

Gudelytè-Račienè, I. The role of unrealized projects in development of social consciousness. K. ŠEŠELGIS' READINGS - 2017. 2017; 9(1): 118-126.
Himmelman, A.T. Collaboration for a Change. Definition, Decision-making models, Roles, and Collaboration Process Guide. Minneapolis: Himmelman Consulting; 2002.

Ismaila, W.A.W., Saidb, I. Integrating the Community in Urban Design and Planning of Public Spaces: A review in Malaysian cities. Procedia - Social and Behavioral Sciences, 2015; 168: 357-364. https://doi. org/10.1016/j.sbspro.2014.10.241

Lastauskienè G., Bakštienè D. Visuomenės interesu apsaugos problema planuojant teritorijas/ Public interest protection problem in the spatial planning process, TEISE், 2015: 96-70.

Morales, J.A. Sustainable Development by Means of A Collaborative Planning Framework The Case of Municipal Housing, Guatemala City. Master Thesis of Geo-Information Science And Earth Observation. Enschede, University of Twente; 2013. 
Proli, S. Improving an urban sustainability environment through community participation: the case of Emilia-Romagna region. Procedia Engineering, 2011; 21: 1118-1123. https://doi.org/10.1016/j.proeng.2011.11.2119

Rasoolimanesh, S.M., Jaafar, M., Ahmad, A.G., Barghi, R. Community participation in World heritage site conservation and tourism development. 2017. Tourism management, 2017; 58: 142-153. https:// doi.org/10.1016/j.tourman.2016.10.016

Ramalis Sobandi and Noviantari Sudarmadji. Knowledge Sharing and Stakeholder Collaboration Practice in Solo City Planning and Development: Notes on Urban Community Nurturing Processes. Procedia Social and Behavioral Sciences, 2015 184: 161 - 170. https://doi.org/10.1016/j.sbspro.2015.05.076

Shuib, K. B., Hashim, H., Nasir, N.A.M. Community participation strategies in planning for urban parks. Procedia - Social and Behavioral Sciences, 2015; 168: 311 - 320. https://doi.org/10.1016/j.sbspro.2014.10.236

Stewart, W.P., Liebert, D., Larkin, K.W. Community identities as visions for landscape change. Landscape and Urban Planning, 2004; 69: 315-334. https://doi.org/10.1016/j.landurbplan.2003.07.005

Urbonaitè, I. Miesto teritorinių bendruomenių itaka rekreacinių teritoriju formavimui [Urban territorial communities and their influence forming urban recreational territories], Mokslas - Lietuvos ateitis. K. Šešelgio skaitymai - 2011 [Science - Future of Lithuania. K. Šešelgis Readings - 2011], 2011; 3(3): 30-37.

Lietuvos Respublikos teritoriju planavimo istatymo pakeitimo istatymas. Valstybės žinios, 2013, nr. 763824.

Yin, R. K., Case Study Research. Design and Methods, 1984: 23.Received: 18102017

\section{GERDA ANTANAITYTÉ}

Project coordinator

Architect A.Zaviša Charity and Support Foundation

\section{Lecturer}

Klaipeda University, Faculty of Humanities and Education Sciences, Department of Philosophy and Culturology

\section{Main research area}

Phenomenology in architecture, intersection of culture, society and space

\section{Address}

Turgaus g. 8-14, Klaipèda

Tel. +37061706767

E-mail: antanaityte.gerda@gmail.com

\section{INGA URBONAITĖ-VADOKLIENĖ}

Director at LCC innovation lab

LCC innovation lab, LCC international university

\section{Main research area}

Public spaces, community involvement, creative thinking, architecture and urban design

\section{Address}

Kretingos g. 36, Klaipèda

Tel. 862091989

E-mail: inga.urbonaite@yahoo.com

\section{About the authors}

